\title{
La gubia ósea como instrumento escultor del pliegue nasolabial. Nota técnica
}

\section{Bone rongeur as nasolabial fold sculptor instrument. A technical note}

\author{
M.Y. Mommaerts' ${ }^{1}$ B. Ramos Medina ${ }^{2}$
}

Resumen: Los pliegues nasolabiales prominentes son uno de los aspectos que más preocupan a los pacientes candidatos a un lifting facial, y han sido descritas muchas técnicas que intentan atenuar este signo distintivo del envejecimiento. Las sustancias de relleno tienen limitaciones inherentes. Las disecciones amplias del SMAS y su posterior suspensión no tienen efecto después de transcurridas 24 horas. La suspensión de la almohadilla grasa malar tiene un efecto que se extiende como máximo a los dos años de duración. La extirpación directa de la grasa lateralmente al surco nasolabial, aunque debe hacerse con mucha cautela, es la única técnica que proporciona resultados permanentes. Técnicamente, esta resección grasa se ha descrito realizada valiéndose de pinzas y tijeras, con cánulas de liposucción o con curetas. Este procedimiento requiere un control muy preciso, táctil y visual, de la localización y profundidad de la extirpación, control que puede mejorarse usando una gubia ósea con una mano para extirpar la grasa a eliminar de la dermis, mientras la otra mano maneja el colgajo cutáneo de la mejilla, para un control alternativo interno y externo del efecto escultural de la extirpación y para permitir una guía táctil externa.

Palabras clave: Ritidoplastia; Rejuvenecimiento; Instrumentos quirúrgicos.

Recibido: 07.12.2005

Aceptado: 16.06 .2008

\begin{abstract}
Prominent nasolabial folds are of concern to many face lift candidates. Many techniques have been described which tackle this distinct sign of ageing. Crease fillers have inherent limitations. Extended SMAS dissection and suspension has no effect after 24 hours. Malar fat pad suspension has an effect which extends maximally to 2 years. Direct fat excision lateral to the crease must be done cautiously. However, it is the only technique providing permanent results. Fat removal can be done with tweezers and scissors, with liposuction canules, and with curettes. Tactile and visual control over location and depth of the resection is required. Such is possible when using a bone rongeur in one hand to reduce the fat mount which has been dissected off the dermis. The other hand turns over the cheek flap for alternating internal and external control of the sculpturing effect, and for external tactile guidance.
\end{abstract}

Key words: Rhytidoplasty; Rejuvenation; Surgical Instruments.

1 Staff surgeon

2 Visiting surgeon (Cartagena-Murcia)

Servicio de Cirugía Maxilo-Facial

AZ St. Jan, Brugge, Bélgica

\section{Correspondencia:}

Maurice Y. Mommaerts, MD, DMD, PhD, FEBOMFS

AZ St. Jan, Ruddershove 10

B-8000 Brugge. Bélgica

Email: maurice.mommaerts@azbrugge.be 


\section{Introducción}

El surco nasolabial está ausente en los recién nacidos y en los pacientes con parálisis facial, indicando que el tono y actividad musculares son determinantes para su presencia y localización. En el comienzo de la cuarta década, el pliegue nasolabial se hace más prominente, y aparecerán el pliegue labiomandibular y un progresivo descenso de las mejillas (jowling). Estos primeros signos de envejecimiento inducen a algunas personas a buscar soluciones y consejo para la realización de una ritidoplastia.

El surco nasolabial viene determinado por la inserción del SMAS y de los músculos de la mímica que elevan el labio y la comisura oral. Lateralmente al surco se encuentra el pliegue nasolabial, formado por piel y grasa subcutánea con grosor variable, ${ }^{1}$ y que es mantenido por un septo fibroso entre el SMAS y la grasa suprayacente..$^{2,3} \mathrm{Al}$ final de la tercera década, la piel de la mejilla pierde su elasticidad y el septo fibroso se ve interrumpido por la acción muscular de la mímica, de forma que la piel y la grasa subcutánea comienzan a deslizarse hacia delante y hacia abajo sobre el SMAS subyacente. Como el surco nasolabial permanece en su posición con el envejecimiento, la piel lateral al mismo y la grasa subcutánea se pliegan sobre sí mismas.

Las inserciones dérmicas del depresor anguli oris forman la parte superior del surco del pliegue labiomandibular, ${ }^{4}$ mientras el ligamento osteocutáneo mandibular forma la parte inferior del mismo. ${ }^{5}$ Lateralmente se encuentra la grasa de la mejilla. El pliegue labiomandibular se acentúa con la sonrisa por la acción del platisma. ${ }^{4}$

Dado que los pliegues nasolabial y labiomandibular se hacen aparentes con la edad por acción de la gravedad sobre la piel y la grasa subcutánea, tiene sentido "levantar" estos dos componentes, bien como una unidad o de forma separada. Hamra describió la reposición de la grasa de la mejilla como parte de un procedimiento de lifting facial en plano profundo (deep plane face lift) en 1990, y comunicó resultados notables en la zona del pliegue nasolabial. ${ }^{6}$ Sin embargo, en el año 2002 el mismo autor admitía que con los lifting faciales en plano profundo los pliegues nasolabiales recurrían transcurridos 1 ó 2 años, y dejó establecido que solo la excisión directa de la grasa produce una corrección permanente del pliegue nasolabial. ${ }^{7}$

El autor senior (Mommaerts) estudió la técnica de extirpación directa de la grasa con Millard en 1989. Millard marcaba externamente el pliegue nasolabial con dos catéteres. Cuando se disecaba y liberaba la dermis con el bisturí, la disección se profundizaba moderadamente a nivel del pliegue nasolabial, por debajo de su cresta grasa, que se dejaba adherida a la piel. ${ }^{8}$ Esta parte de la disección se hacía a ciegas. El exceso de grasa se eliminaba de la piel suprayacente con pinzas y tijeras de gran longitud, ahora bajo visión directa.

\section{Técnica quirúrgica}

El problema cuando se usan pinzas y tijeras es que las dos manos y los ojos deben unir esfuerzos para extirpar la grasa, un cirujano ayudante debe separar el colgajo cutáneo, y la correlación entre

\section{Introduction}

The nasolabial crease is absent in newborns and in patients with facial paralysis, indicating that muscular tone and action are determining its presence and location. At the beginning of the fourth decade, the nasolabial fold becomes more prominent and the labiomandibular fold and jowling appear. These first signs of ageing prompt some people to seek advice for rhytidoplasty

The nasolabial crease is determined by the insertion of the SMAS and the mimetic muscles that elevate the lip and the corner of the mouth. Lateral to the crease is the fold, which comprises skin and subcutaneous fat of variable thickness. 1 Fibrous septae between the SMAS and the overlying fat maintain the fold. ${ }^{2,3}$ At the end of the third decase, the cheek skin loses its elasticity and the septae are disrupted by mimetic action. The skin and subcutaneous fat of the fold start to slide forward and down over the underlying SMAS. As the nasolabial crease remains in position with ageing, the posterior skin and fat fold on themselves.

Dermal insertions of the depressor anguli oris form the superior crease of the labiomandibular fold ${ }^{4}$ and the osteocutaneous mandibular ligament the lower part. ${ }^{5}$ Lateral is cheek fat. The labiomandibular fold is accentuated by smiling due to platysma pull. ${ }^{4}$

Since nasolabial and labiomandibular folds are appearing with age, and caused by the action of gravity on fat and skin, it makes sense to lift these two components, whether as a unit or in a separate way. Hamra described repositioning of the cheek fat as part of a deep plane face lift in 1990, and reported remarkable results in the nasolabial fold area. ${ }^{6}$ However; in 2002 the same author admitted that with deep plane face lifts, the nasolabial folds recurr after 1 or 2 years. He stated that only direct excision will produce a permanent correction of the nasolabial fold.?

The senior author (Mommaerts) studied the technique of direct fat excision with Millard in 1989. Millard marked out the nasolabial fold with 2 catheters. During the scalpel freeing of the dermis, the dissection was carried moderately deeper at the nasolabial fold, slicing off its fatty crest, which was left attached to the skin. ${ }^{8}$ This dissection was done blindly. The excess fat was removed from the skin's undersurface with long scissors and long tweezers, under direct vision.

\section{Surgical technique}

The problem when using tweezers and scissors is that both hands and the eyes have to join efforts to snip the fat. An assisting surgeon has to retract the skin flap. To correlate the image of the subcutaneous situation with the external facial anatomy is difficult, time consuming and traumatic for the surgeon's spine.

There are the options to leave the fat on the skin side or on the muscle side, before resecting it with bone 
la imagen de la situación subcutánea y la anatomía facial externa es difícil, consume mucho tiempo y es traumática para la espalda del cirujano.

Existen las opciones de dejar la grasa en el lado cutáneo o en lado muscular de la disección, antes de que sea extirpada con la gubia ósea. La gubia ósea permite coger los lóbulos grasos fácilmente y empujarlos para comprobar externamente la localización y el volumen de la reducción, y todo ello con una sola mano (Fig. 1). La otra mano separa el colgajo cutáneo y permite controlar tácticamente el resultado de la reducción grasa durante el procedimiento. La

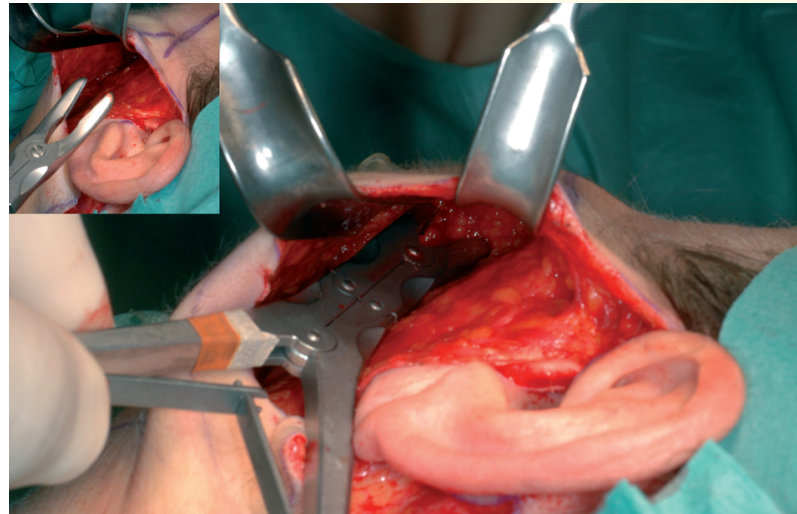

Figura 1. La gubia ósea siendo usada para esculpir la almohadilla grasa bajo el colgajo del lifting facial.

Figure 1. Bone rongeur (arrow) which is used to tailor the fat mounds under the face lift flap. rongeurs. Bone rongeurs enable to grasp the fat lobules more easily, to pull on them to verify externally the location for volume reduction; all that with one hand (Fig. 1). The other hand retracts the skin flap and controls also tactically the result of the fat reduction during the procedure. Bone rongeurs remove fat by a pulling and cutting action. By uniform action along the length of the fold, there is less risk for visible depressions in the sculpted areas as is the case with the scis- mediante un mecanismo de corte y trac-

ción, y mediante una acción uniforme a lo largo del pliegue nasolabial, hay menor riesgo de depresiones visibles en las zonas esculpidas que usando pinzas y tijeras. En ocasiones usamos una gubia más fina y picuda para disecar la grasa de la zona entre la piel y el músculo orbicularis oris, debajo del surco nasolabial. Prácticamente todo el procedimiento puede hacerse con control externo visual y táctil, tanto en el pliegue nasolabial como en el pliegue labiomandibular. Tan solo en la zona más colgante de la mejilla verificamos internamente la profundidad de la extirpación grasa.

\section{Discusión}

En las últimas dos décadas, los cirujanos que realizan lifting faciales han explorado muchas técnicas para manejar adecuadamente la ptosis mediofacial. Por supuesto, la reducción de los pliegues nasolabiales ocupa un lugar prioritario para los pacientes candidatos a una ritidoplastia.

La suspensión del SMAS tiene un efecto permanente sobre la ptosis de las mejillas, pero no sobre la reducción de los pliegues nasolabiales. Ivy y cols. (1996) ${ }^{9}$ compararon el lifting con disección amplia del SMAS con las SMASectomías laterales, el lifting con disección convencional del SMAS y el lifting con colgajos compuestos. El colgajo compuesto traccionado con gran tensión producía el mayor efecto sobre el pliegue durante la cirugía. Sin embargo, después de 24 horas las diferencias entre los cuatro tipos de lifting desaparecían para siempre. Youssif y cols. (1994) 2 comunicaron resultados intraoperativos similares.

La reposición de la almohadilla grasa malar fue propuesta por primera vez por Hamra (1990). ${ }^{6}$ Owsley $(1993,1995)^{1,10}$ describió la sutura de suspensión de la almohadilla grasa y Stuzin y cols. (1993) ${ }^{11}$ enfatizaron posteriormente la importancia de una sutura de suspensión permanente. Hamra, ${ }^{7}$ admitió en 2002 que también esta técnica estaba condenada a la recidiva tras algunos años.

La sección de las inserciones dérmicas de los músculos de la mímica en la zona del surco nasolabial no está indicada, pues las inserciones musculares, aunque fijan el surco, son responsables sors and tweezers technique. We sometimes use a finebeaked rongeur to dissect in between the skin and the orbicularis oris muscle, beyond the crease. Nearly all action can be done with external visual and tactile control, both in the nasolabial fold, and labiomandibular fold. Only for the sagging jowl we verify more internally the depth of the fat resection.

\section{Discussion}

In the last two decades, face lift surgeons have explored many techniques to address midfacial ptosis properly. Indeed, reduction of the nasolabial fold is high on the priority list of rhytidoplasty candidates.

SMAS suspension has a permanent effect on the sagging jowls, but not on the nasolabial folds. Ivy et al. (1996)9 compared extended SMAS face lifts with lateral SMASectomies, conventional SMAS face lifts and composite flap lifts. The composite flap pulled with great tension exerted the largest effect on the fold during the surgery. However, after 24 hours the difference between the 4 types of lifts was lost for ever. Youssif et al. (1994) ${ }^{2}$ reported similar intraoperative findings.

Repositioning of the malar fat pad was first undertaken by Hamra (1990). ${ }^{6}$ Owsley $(1993,1995)^{1,10}$ described suture suspension of the advanced fat pad and Stuzin et al. (1993)11 further underlined the importance of permanent suture suspension. Hamra ${ }^{7}$ admitted in 2002 that also this technique was prone to relapse after some years.

Severing the dermal attachments of the mimetic muscles in the crease area is not advocated. The muscular insertions are fixing the crease but they also responsible for individual smile characteristics. ${ }^{12}$ Although release of the cutaneous insertion of these muscles would allow the skin to glide more superiorly with traction on the flap, and smooth the crease, ${ }^{3}$ trauma to the muscle insertions could lead to sag- 
de las características de la sonrisa individual. ${ }^{12}$ Aunque la liberación de las inserciones cutáneas de estos músculos permitirían a la piel deslizarse más superiormente con la tracción del colgajo y aplanar el surco, ${ }^{3}$ el trauma a las inserciones musculares podría producir un desplazamiento de la comisura de la boca y cambiar el patrón de la sonrisa del paciente, algo que también podría producirse si los músculos no se reinsertan en la dermis.

Una lipectomía subcutánea juiciosa y la posterior tracción de la piel facial liberada se ha probado un método eficiente. ${ }^{13}$ Se han empleado cánulas de liposucción para facilitar ésto. ${ }^{14}$ Ellenbogen y cols. (1989) ${ }^{15}$ proclaman que las curetas son superiores a la succión grasa. Nosotros describimos una técnica usando gubias óseas para esculpir la almohadilla grasa.

\section{Bibliografía}

1. Owlsey JQ. Lifting the malar fat pad for correction of prominent nasolabial folds. Plast Reconstr Surg 1993;91:463-74.

2. Youssif NJ, Gosain A, Matloub HS, Sanger JR, Madiedo G, Larson D. The nasolabial fold: an anatomic and histological reappraisal. Plast Reconstr Surg 1994;93:60-9.

3. Pogrel MA, Shariati S, Schmidt B, Faal ZH, Regezi J. The surgical anatomy of the nasolabial fold. Oral Surgery Oral Medicine Oral Pathology 1998;86:410-5.

4. Pessa JE, Garza PA, Love VM, Zadoo VP, Garza JR. The anatomy of the labiomandibular fold. Plast Reconstr Surg 1998;101:482-6.

5. Furnas DW. The retaining ligaments of the cheek. Plast Reconstr Surg 1989;83:116.

6. Hamra ST. The deep plane rhytidectomy. Plast Reconstr Surg 1990;86:53-61.

7. Hamra ST. A study of the long-term effect of malar fat repositioning in face lift surgery: short-term success but long-term failure. Plast Reconstr Surg 2002;110: 940-51.

8. Millard DR Jr, Yuan RT, Devine JW Jr. A challenge to the undefeated nasolabial folds. Plast Reconstr Surg 1987;80:37-86.

9. Ivy EJ, Lorenc ZP, Aston SJ. Is there a difference? A prospective study comparing lateral and standard SMAS face lifts with extended SMAS and composite rhytidectomies. Plast Reconstr Surg 1996;98:1135-47.

10. Owlsey JQ. Elevation of the malar fat pad superficial to the orbicularis oculi muscle for correction of prominent nasolabial folds. Clin Plast Surg 1995;22:279-93.

11. Stuzin JM, Baker TJ, Gordon HL. Lifting the malar fat pad for correction of prominent nasolabial folds. Plast Reconstr Surg 1993;91:475-6.

12. Barton FE, Gyimesi HM. Anatomy of the nasolabial fold. Plast Reconstr Surg 1998; 100:1276-9.

13. Millard DR Jr. Mullin WR, Hunsaker RH. Evaluation of a technique designed to correct nasolabial folds. Plast Reconstr Surg 1992;89:356-365.

14. McKinney P, Cook JQ. Liposuction and the treatment of nasiolabial folds. Aesthetic Plast Surg 1989;13:167-77.

15. Ellenbogen R, Wethe J, Jankauskas S, Collini F. Curette fat sculpture in rhytidectomy: improving the nasolabial and labiomandibular folds. Plast Reconstr Surg 1991;89:767-8. ging of the corner of the mouth and a change in the smile pattern. It remains also to be seen if the muscles would not reattach to the dermis!

Judicious subcutaneous lipectomy and posterior traction to the freed facial skin has been proven efficacious. ${ }^{13}$ Canule suction has been proposed to facilitate this. ${ }^{14}$ Ellenbogen et al. (1989)15 claimed that curettes are superior to fat suction. We described a technique using bone rongeurs to sculpt the fat pad. 